Article

\title{
Forage Warm-Season Legumes and Grasses Intercropped with Corn as an Alternative for Corn Silage Production
}

\author{
Renata La Guardia Nave * and Michael Dereck Corbin \\ Department of Plant Sciences, University of Tennessee, Knoxville, TN 37996, USA; mcorbin1@utk.edu \\ * Correspondence: rnave@utk.edu; Tel.: +1-931-486-2129; Fax: +1-931-486-0141
}

Received: 10 August 2018; Accepted: 16 September 2018; Published: 21 September 2018

\begin{abstract}
Intercropping of forage grasses and legumes can increase forage productivity and nutritive value; however, intercropping of corn with warm-season forages has not yet been studied in southeast U.S., thus requiring more information. The purpose of this study was to determine the yield and nutritive value potential of warm-season annual forages intercropped with corn (Zea mays L.) for silage production. Crabgrass [Digitaria sanguinalis (L.)] is considered a weed for corn production systems; however, our study shows that if crabgrass is interseeded with corn, it does not compete for resources and can maintain high corn yields. Forage mass for sunn hemp (Crotalaria juncea L.) was higher than that of cowpea [Vigna unguiculata (L.) Walp.] and crabgrass in 2016, due to a drought in spring and summer, giving sunn hemp a competitive advantage. Crude protein content was higher for cowpea as compared to crabgrass and sunn hemp, due to cowpea's ability to maintain its vegetative stage and high N-fixation, when compared to crabgrass and sunn hemp. Despite differences in the mass of the intercropped forages, the total herbage mass of the produced silage did not differ in 2016 and 2017. Intercropped forages can be harvested and ensiled with corn for silage production or can be left with the corn residue after harvesting to be grazed on in integrated crop-livestock systems.
\end{abstract}

Keywords: intercropping systems; warm-season forages; corn silage

\section{Introduction}

Intercropping is a system where two or more species are grown on the same land at the same time. One of the benefits of intercropping is improved land use efficiency [1]. Intercropping of grass with legumes is reported to increase forage productivity [2] and nutritive value [3]; however, intercropping of annual cash crops (such as corn) with warm-season forages in southeast U.S. has not yet been studied.

Forage crops have been identified as important components of diversified intercropping systems, reducing irrigation water use [4], improving soil erosion protection [5], decreasing nutrient losses through leaching and runoff [6], increasing C sequestration [7], increasing weed suppression [8], and providing critical habitat for wildlife [9]. When forage crops are used within intercropping systems, the producers gain long-term environmental and soil quality benefits, while potentially achieving short-term economic value within their operations [10].

In South America, the most common intercropping system is corn with palisadegrass [Brachiaria brizantha (Hochst. Ex A. Rich.) Stapf] [11], due to a large number of cultivars in different ecological regions growing corn, and because of the excellent adaptation of corn plants in intercropping systems [12]. In the early stages of development, palisadegrass shows slow growth, and corn with its higher rate of dry matter accumulation provides excellent characteristics for intercropping with smaller species [12]. Therefore, in most cases, the intercropping of palisadegrass with corn does not reduce corn yields [13]. However, in the Unites States, most intercropping systems are composed of grain 
species with legumes $[1,6,8,14]$. The purpose of this study was to investigate the potential of three different forage crop species intercropped with corn for silage production and determine the effect on yield and nutritive value of both crops. The hypothesis was that intercropping of forage grass or legumes with corn would not negatively impact corn silage production, would increase sustainability of the system, and provide additional forage to be later harvested or grazed upon.

\section{Material and Methods}

\subsection{Site Description and Experimental Design}

This study was conducted at the Middle Tennessee AgResearch and Education Center (MTREC) in Spring Hill, TN. The soil type in the study location is Maury silt loam, which is a Typic Paleudalf. Initial soil samples were collected in January 2016 at a depth of $15 \mathrm{~cm}$ and sent to the laboratory at University of Tennessee Soil, Plant and Pest Center for analysis [15]; no micronutrient deficiencies were found across the site. Mean soil $\mathrm{pH}$ was 6.7. Based on Mehlich 1 soil extractions, mean phosphorus was $198 \mathrm{~kg} \mathrm{ha}^{-1}$, potassium was $120 \mathrm{~kg} \mathrm{ha}^{-1}$, calcium was $2519 \mathrm{~kg} \mathrm{ha}^{-1}$, and magnesium was $205 \mathrm{~kg} \mathrm{ha}^{-1}$.

The experimental periods were June to September 2016, and May to September 2017. The experimental design was a completely randomized block with four treatments and three replications per treatment $(n=12)$. The treatment plans were as follows: (1) corn grown for silage as a monoculture (C); (2) corn grown for silage intercropped with cowpea (CCW); (3) corn grown for silage intercropped with crabgrass (CCR); and (4) corn grown for silage intercropped with sunn hemp (CS). Individual plots measured $4.6 \mathrm{~m} \times 12.2 \mathrm{~m}$. In 2015, the year prior to the experimental period, soybeans were grown in the field. In the period between growing seasons, the field was fallow.

On 2 June 2016, corn, cv. Cropland DS93RR2 hybrid was sown at a 3-cm depth at a density of 83,980 seeds ha ${ }^{-1}$. On that same date, in intercropping treatments, cowpea cv. Iron \& Clay was sown at $56 \mathrm{~kg} \mathrm{ha}^{-1}$; sunn hemp was sown at $45 \mathrm{~kg} \mathrm{ha}^{-1}$; and crabgrass cv. Mojo was sown at $6.7 \mathrm{~kg} \mathrm{ha}^{-1}$. Cowpea, sunn hemp and crabgrass were planted using a Hege 1000 series plot drill (Hege Company, Waldernburg, Germany, F.R.) and corn was planted using a John Deere 7100 four row plot planter. Cowpea and sunn hemp were treated with $\mathrm{N}$-Dure seed inoculant as per label instructions immediately prior to planting. Corn was sown on 76- $\mathrm{cm}$ row spacing, and all other intercropped forages were planted on 18-cm row spacing. On 9 May 2017, corn and intercropping systems were planted following the same guidelines described above, including the use of the same cultivars and seed inoculant.

On 27 May 2016 and 16 May 2017, all plots received a broadcast fertilizer application consisting of $89.7 \mathrm{~kg} \mathrm{ha}^{-1}$ of $\mathrm{N}$ applied as ammonium nitrate; $78 \mathrm{~kg} \mathrm{ha}^{-1}$ applied as super phosphate; and $156 \mathrm{~kg}$ ha $^{-1}$ of K applied as potash. On 27 May 2016 and 8 May 2017, Gramoxone ${ }^{\circledR}$ Paraquat herbicide was applied to all plots to control weeds, thus acting as a desiccant/defoliant herbicide.

\subsection{Measurements}

To characterize the mass and nutritive value of the intercropped forage crops, all plots with the exception of $C$ treatment were sampled once a month after establishment, with sampling dates occurring on 22 July, 15 August and 8 September in 2016; and 21 July, 22 August and 12 September in 2017. The samples were randomly collected from a $0.1 \mathrm{~m}^{2}$ area at a $5-\mathrm{cm}$ stubble height, dried at $60^{\circ} \mathrm{C}$ to a constant weight $(\sim 72 \mathrm{~h})$, and dry weights were recorded to determine forage mass. The samples were ground to pass through a 1-mm sieve with a Wiley Mill Grinder (Thomas Scientific, Swedesboro, NJ, USA) in preparation for near-infrared spectroscopy (NIRS) analysis. Three forage nutritive value parameters-crude protein $(\mathrm{CP})$, neutral detergent fiber (NDF) and in vitro true dry matter digestibility (IVTDMD)—were predicted using a Unity SpectraStar XT near infrared spectroscopy (NIR) instrument (Unity Scientific, Milford, MA, USA).

Equations for the forage nutritive analyses were standardized and checked for accuracy with the 2014 Grass Hay Equation, developed by the NIRS Forage and Feed Consortium (NIRSC, Hillsboro, WI, USA). The software used for NIRS analysis was Win ISI II supplied by Infrasoft International 
(State College, PA, USA). The Global $H$ statistical test was used to compare the samples against the model and samples from distinct data sets within the database for accurate results; all forage samples fit the equation $(H<3.0)$, and are reported accordingly [16].

In addition, corn plant population, height of main ear insertion, and corn plant height were evaluated monthly, on the same dates described above. Plant population was determined by counting the number of plants in the two central rows of each plot, and the corn plant height and height of main ear insertion was determined from 10 plants per plot chosen at random.

\subsection{Silage Composition}

On 8 September 2016 and 12 September 2017, the two center rows from all plots were harvested using a John Deere corn silage chopper combined with a weigh wagon (Henkie Buffalo TMR mixer) to determine total silage herbage mass. Green weight was determined for the total harvested silage, and then a sub-sample was collected and dried at $60^{\circ} \mathrm{C}$ to a constant weight $(\sim 72 \mathrm{~h})$ to determine total silage herbage mass on a dry matter basis. Both corn and intercropped forages were harvested together for silage composition.

From the chopped harvested material, a well-mixed sub-sample of approximately $2000 \mathrm{~g}$ was then packed into small silos (20-L cylinders with lids). Each silo was topped with a heavy rod to assure appropriate compaction. The silos were then tightened and placed in a dark room at $30^{\circ} \mathrm{C}$ for 35 days, after which they were opened and a sub-sample immediately collected and dried at $60^{\circ} \mathrm{C}$ to a constant weight $(\sim 72 \mathrm{~h})$. The samples were then ground to pass through a 1-mm sieve with a Wiley Mill Grinder (Thomas Scientific, Swedesboro, NJ, USA) in preparation for near-infrared spectroscopy (NIRS) analysis. Three forage nutritive value parameters-crude protein (CP), neutral detergent fiber (NDF) and in vitro true dry matter digestibility (IVTDMD)—-were predicted as described above.

\subsection{Statistical Analysis}

Differences between the least square means by treatment for corn agronomic characteristics, nutritive value variables, intercropped forage mass, and silage herbage mass, and nutritive value variables were evaluated using PROC MIXED procedures, adjusted for Tukey's method for least square means separation, of SAS (SAS for Windows V 9.4, SAS Institute, Cary, NC, USA). Response variables (plant population, ear height, plant height, forage mass, $\mathrm{CP}, \mathrm{NDF}$, IVTDMD) were considered dependent; year, month and treatment were considered fixed effects; and replicates were considered random effect. There were significant year $\times$ treatment interactions $(p<0.0001)$ for all dependent variables. Therefore, the results of each experiment are displayed separately by year for all variables.

\section{Results and Discussion}

\subsection{Weather}

During the growing season in 2016 (April through September), rainfall averaged $88.9 \mathrm{~mm}$, which was $21 \%$ below the 30 -year average (Figure 1). These values were especially lower during early spring in April and May 2016, with an average of $45.7 \mathrm{~mm}$. In 2017, rainfall during the same period (April through September) averaged $145.6 \mathrm{~mm}$, which was $30 \%$ above the 30 -year average (Figure 1). The mean air temperature during the growing season in 2016 was $4 \%$ higher than the 30-year average, and 6\% higher in 2017 (Figure 1). 


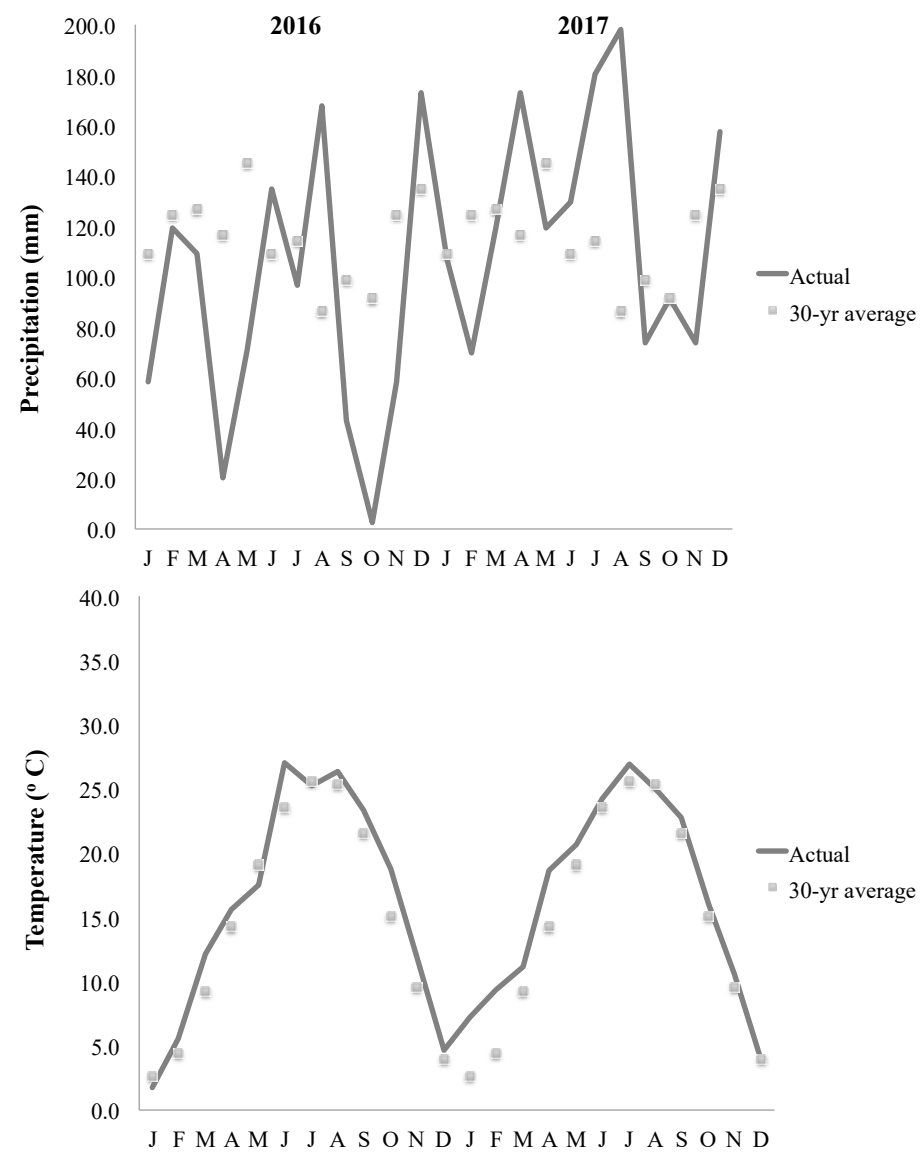

Figure 1. Weather for Middle Tennessee AgResearch and Education Center, Spring Hill, TN, 2015-2017, including 30-year average.

\subsection{Corn Characteristics}

Overall during both years, plant populations were lower than usual for U.S. corn silage production. Corn planting in Middle Tennessee is recommended between 1 April and 1 May. However, in order to simultaneously interseed warm-season forages in these plots, planting was delayed, which reduced plant populations.

In 2016, plant population was lower for CS in all months (average of 54,000 plants ha ${ }^{-1}$ ). Sunn hemp has a high drought tolerance and can grow in a wide range of soil types and environments. Due to abnormal drought conditions that occurred in April-May, July and September (Figure 1), sunn hemp appears to have a competitive advantage when intercropped with corn, therefore showing a lower corn plant population. In 2017, it only differed in September, with C having the lowest corn plant population $\left(45,000\right.$ plants ha $\left.^{-1}\right)$ (Table 1$)$. The CCW and CCR treatments had consistently higher plant population in both years. Crabgrass is considered a problematic weed for most grain and corn silage production systems. However, our study shows that if crabgrass is purposely interseeded simultaneously with corn while being well managed, it does not compete for resources, maintaining high corn production. Similar results were observed by the author of [17], where corn plant populations, in corn interseeded with palisadegrass and corn alone, did not differ. The authors added that grass population should be kept low to avoid later competition between the two species. Intercropping of legumes with corn has been investigated as an alternative to enhance sustainability and overall nutritive value [14]. Cowpea has an aggressive growing habit and excellent $\mathrm{N}$-fixing capabilities, making it an attractive choice for intercropping systems [18], and our results are in agreement. 
Table 1. Corn agronomic characteristics (plant population, ear height and plant height) of corn grown alone $(\mathrm{C})$, or interseeded with cowpea (CCW), sunn hemp (CS) or crabgrass (CCR).

\begin{tabular}{|c|c|c|c|c|c|c|c|c|c|c|}
\hline & & \multicolumn{3}{|c|}{$\begin{array}{l}\text { Plant Population (No. } \\
\times 1000)\end{array}$} & \multicolumn{3}{|c|}{ Ear Height (cm) } & \multicolumn{3}{|c|}{ Plant Height (cm) } \\
\hline & & July & August & September & July & August & September & July & August & September \\
\hline \multirow{5}{*}{2016} & CCW & $95^{\mathrm{a}}$ & $97^{a}$ & $96^{a}$ & $55^{\mathrm{a}}$ & $87^{a}$ & $85^{a}$ & $185^{\mathrm{b}}$ & $218^{a}$ & $211^{a}$ \\
\hline & CS & $51^{\mathrm{b}}$ & $51^{b}$ & $50^{b}$ & $0^{\mathrm{b}}$ & $49^{b}$ & $0^{\mathrm{b}}$ & $145^{\mathrm{c}}$ & $157^{b}$ & $158^{b}$ \\
\hline & CCR & $83^{\mathrm{a}}$ & $82^{a}$ & $82^{a}$ & $82^{a}$ & $85^{\mathrm{a}}$ & $88^{a}$ & $204^{\mathrm{ab}}$ & $249^{a}$ & $245^{a}$ \\
\hline & $\mathrm{C}$ & $85^{\mathrm{a}}$ & $82^{a}$ & $82^{a}$ & $87^{\mathrm{a}}$ & $83^{a b}$ & $86^{\mathrm{a}}$ & $234^{\mathrm{a}}$ & $251^{a}$ & $238^{a}$ \\
\hline & $\mathrm{C}$ & & & & & & & & & \\
\hline \multirow{4}{*}{2017} & CCW & $63^{a}$ & $58^{a}$ & $78^{a}$ & & & $80^{a}$ & $238^{a}$ & $251^{a}$ & $241^{a}$ \\
\hline & CS & $55^{\mathrm{a}}$ & $46^{\mathrm{a}}$ & $80^{a}$ & & & $82^{\mathrm{a}}$ & $240^{\mathrm{a}}$ & $245^{\mathrm{a}}$ & $228^{a}$ \\
\hline & CCR & $56^{\mathrm{a}}$ & $54^{\mathrm{a}}$ & $66^{\mathrm{ab}}$ & & & $74^{\mathrm{a}}$ & $235^{a}$ & $243^{a}$ & $234^{\mathrm{a}}$ \\
\hline & $\mathrm{C}$ & $41^{\mathrm{a}}$ & $41^{\mathrm{a}}$ & $45^{b}$ & & & $75^{a}$ & $232^{\mathrm{a}}$ & $237^{a}$ & $234^{\mathrm{a}}$ \\
\hline
\end{tabular}

Means within a column for each month without a common superscript differs $(p<0.05)$.

Regarding ear height, in 2016, CS had the lowest values, but treatments did not differ in 2017 (Table 1). Again, for corn plant height, in 2016, CS again showed the lowest values from July to September, and all treatments were similar in 2017 (Table 1). The drought conditions explained above, combined with sunn hemp's ability to tolerate drought, not only reduced corn plant population, but also reduced ear height and corn plant height. However, in 2017, average and above average precipitation (Figure 1) reduced sunn hemp competitiveness, which was then reflected in the lack of differences for corn production as compared to CCW and CCR (Table 1). Similarly, sunn hemp produced high corn grain yield, serving as an alternative to winter legumes as a cover crop for conservation tillage corn production in southern U.S. [19].

\subsection{Forage Mass and Nutritive Value of Intercropped Forages}

During all months in 2016, the forage mass of sunn hemp was higher than that of cowpea and crabgrass; in 2017, sunn hemp showed higher forage mass only in July and September (Figure 2). In 2016, a drought during spring and summer gave sunn hemp an advantage, leading to a higher-than-normal growth rate. However, even though cowpea and crabgrass showed a lower forage mass as compared to sunn hemp (Figure 2), there was enough forage to be grazed on during fall, when incorporated with integrated crop-livestock systems. For the course of the growing season, crabgrass had an average forage mass of $1860 \mathrm{~kg} \mathrm{ha}^{-1}$ and $3683 \mathrm{~kg} \mathrm{ha}^{-1}$ for 2016 and 2017, respectively. These results are in agreement with past research showing that crabgrass grown as a monoculture has average forage mass between 1500 and $3000 \mathrm{~kg} \mathrm{ha}^{-1}$ in July [20]. A study looking at total crabgrass yield during the season (as impacted by nitrogen fertilization) showed that when crabgrass is produced without $\mathrm{N}$ fertilizer, it yields an average of $4150 \mathrm{~kg} \mathrm{ha}^{-1}$ [21].
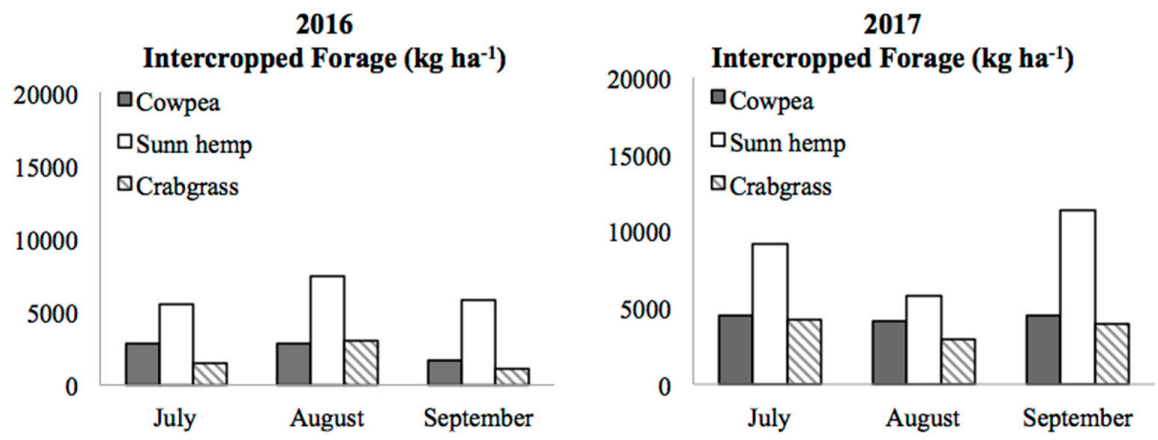

Figure 2. Herbage mass differences $(p<0.05)$ of the forage crops intercropped with corn during the growing season in 2016 and 2017. 
Cowpea had an average forage mass of $2446 \mathrm{~kg} \mathrm{ha}^{-1}$ and $4350 \mathrm{~kg} \mathrm{ha}^{-1}$ in 2016 and 2017, respectively. Cowpea intercropped with grain sorghum production systems have shown average cowpea forage mass of $5300 \mathrm{~kg} \mathrm{ha}^{-1}$ [18], results that are in agreement with our current study. Sunn hemp, when produced as a monoculture, has an average forage mass of up to $25,000 \mathrm{~kg} \mathrm{ha}^{-1}$ [22]. In our study, average forage mass of sunn hemp was $6253 \mathrm{~kg} \mathrm{ha}^{-1}$ and $8753 \mathrm{~kg} \mathrm{ha}^{-1}$ in 2016 and 2017, respectively. A study investigating sunn hemp as a cover crop for corn production reported that sunn hemp averaged $7600 \mathrm{~kg} \mathrm{ha}^{-1}$, which is similar to our results [19]. Overall, intercropping systems did not reduce corn productivity or intercropped forage mass. Similarly, intercropping yields of corn and palisadegrass were not affected, resulting in high amounts of residue and improvement in nutrient cycling [23]. Corn has a higher rate of accumulation in the early stages of development due to its high capacity for light interception [24], therefore it is less affected by competition with annual grasses and legumes.

During July and August of both years, $\mathrm{CP}$ content was higher for cowpea as compared to crabgrass and sunn hemp (Table 2). This is expected, since cowpea is a warm-season legume with the ability of $\mathrm{N}$-fixation, therefore higher $\mathrm{CP}$ content is produced when compared to a warm-season grass such as crabgrass. Cowpea is a good alternative for intercropping systems without the need for $\mathrm{N}$-fertilization. Sunn hemp is considered a tropical legume with high and rapid accumulation of mass during summer months with elevated temperature. The rapid mass accumulation increases its stem elongation and with advanced maturity, forage nutritive value decreases. In July of 2017, CP content did not differ among these three forages, and that is because shortly after establishment, all plants had a high percentage of immature leaves, which resulted in higher $\mathrm{CP}$ concentration.

Table 2. Nutritive value (crude protein, CP; neutral detergent fiber, NDF and in vitro true dry matter digestibility, IVTDMD) of the forage crops intercropped with corn during the growing season in 2016 and 2017.

\begin{tabular}{|c|c|c|c|c|c|c|c|c|c|c|}
\hline & & \multicolumn{3}{|c|}{$\mathrm{CP}\left(\mathrm{g} \mathrm{kg}^{-1}\right)$} & \multicolumn{3}{|c|}{ NDF $\left(\mathrm{g} \mathrm{kg}^{-1}\right)$} & \multicolumn{3}{|c|}{ IVTDMD $\left(\mathrm{g} \mathrm{kg}^{-1}\right)$} \\
\hline & & July & August & September & July & August & September & July & August & September \\
\hline \multirow{3}{*}{2016} & Cowpea & . & $205^{a}$ & $159^{\text {a }}$ & . & $438^{b}$ & $467^{b}$ & . & $811^{\mathrm{a}}$ & $766^{\mathrm{a}}$ \\
\hline & $\begin{array}{l}\text { Sunn } \\
\text { hemp }\end{array}$ & · & $177^{\mathrm{b}}$ & $113^{b}$ & . & $524^{\mathrm{ab}}$ & $615^{a}$ & · & $718^{b}$ & $608^{b}$ \\
\hline & $\begin{array}{c}\text { Crabgrass } \\
\text { C }\end{array}$ & . & $165^{b}$ & $110^{\mathrm{b}}$ & . & $561^{a}$ & $643^{a}$ & . & $743^{a b}$ & $673^{b}$ \\
\hline \multirow{3}{*}{2017} & Cowpea & $195^{\mathrm{a}}$ & $192^{\mathrm{a}}$ & $218^{a}$ & $305^{b}$ & $324^{b}$ & $319^{c}$ & $937^{\mathrm{a}}$ & $916^{\mathrm{a}}$ & $884^{\mathrm{a}}$ \\
\hline & $\begin{array}{l}\text { Sunn } \\
\text { hemp }\end{array}$ & $172^{a}$ & $120^{b}$ & $123^{b}$ & $390^{\mathrm{b}}$ & $519^{a b}$ & $505^{b}$ & $874^{\mathrm{a}}$ & $729^{b}$ & $728^{b}$ \\
\hline & Crabgrass & $147^{\mathrm{a}}$ & $97^{\mathrm{b}}$ & $67^{b}$ & $572^{\mathrm{a}}$ & $634^{\mathrm{a}}$ & $724^{\mathrm{a}}$ & $768^{b}$ & $707^{b}$ & $617^{c}$ \\
\hline
\end{tabular}

As for NDF concentration, cowpea has shown lower values overall, especially at the end of the growing season in September, when sunn hemp and crabgrass reached its maturity (Table 2), reducing its leaf: stem ratio. In contrary, crabgrass had, for most of the growing season, consistent higher NDF concentration. Similarly, IVTDMD followed the same trend, with cowpea having the highest digestibility in both years and crabgrass having the lowest (Table 2). Sunn hemp showed intermediate values; in the beginning of the growing season, it showed similar NDF and IVTDMD values as that of cowpea, but those were reduced with its rapid accumulation of forage mass.

\subsection{Harvested Herbage Mass for Silage Production and Silage In Vitro Dry Matter Digestibility}

Despite differences in forage mass of the intercropped forages, the total herbage mass of the silage of corn and corn, intercropped with forages, did not differ in both years (Figure 3). A study on the production responses of corn grown for silage, intercropped with tropical forage grasses, has shown a similar forage mass of silage averaging 14-ton ha ${ }^{-1}$ [25]. In 2016, total silage herbage mass was lower than 2017 for all treatments, due to the drought that occurred during the spring and late summer 
of 2016. Forage crops are more competitive and have greater shade adaptability, thus accumulating sufficient forage mass in intercropping systems [25]. Yields of corn and lablab bean [Lablab purpureus (L.) Sweet] mixtures produced for silage is highly determined by corn density, and the addition of legumes does not increase the dry matter yield of monoculture corn [26].

2016

Harvested herbage mass for silage (ton ha-1)

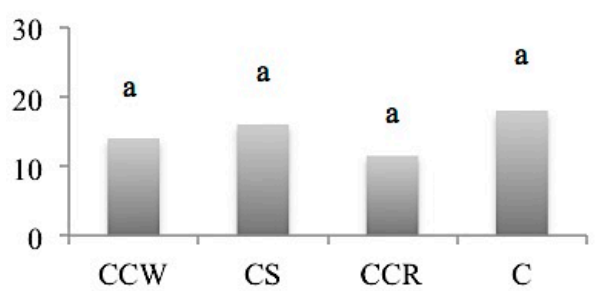

2017

Harvested herbage mass for silage

(ton ha-1)

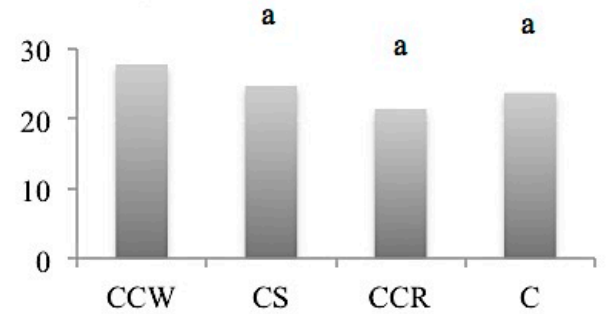

Figure 3. Herbage mass differences $(p<0.05)$ of the harvested corn grown alone $(C)$, or interseeded with cowpea (CCW), sunn hemp (CS) or crabgrass (CCR) for silage production.

In vitro dry matter digestibility was analyzed for silage of corn and corn intercropped with forages in 2016 and 2017, in order to estimate average nutritive value of the silage. Silage composed of CCW and C had the highest IVTDMD values (701 $\mathrm{g} \mathrm{kg}^{-1}$ and $627 \mathrm{~g} \mathrm{~kg}^{-1}$ respectively) during 2016; however, C did not differ from CS and CCR, which had the lowest values (583 $\mathrm{g} \mathrm{kg}^{-1}$ and $549 \mathrm{~g} \mathrm{~kg}^{-1}$ respectively) (Figure 4). In 2017, similar IVTDMD results occurred, with C and CCW showing higher digestibility (584 $\mathrm{g} \mathrm{kg}^{-1}$ and $544 \mathrm{~g} \mathrm{~kg}^{-1}$ respectively); however, CCW did not differ from CS and CCR (Figure 4). In addition, values from 2017 are lower than those from 2016, probably due to the earlier planting date in 2017, which increases the overall maturity of corn and forage crops during silage harvesting. Our results are in agreement with a similar study on forage nutritive value of corn silage grown alone or mixed with lablab beans, in which IVTDMD did not differ, similar to our corn and cowpea mixture [27]. Another study conducted by the same authors ensiling corn with the addition of cowpea showed no differences in IVTDMD; however, their values were slightly higher, ranging from $875 \mathrm{~g} \mathrm{~kg}^{-1}$ when corn was ensiled alone, versus $850 \mathrm{~g} \mathrm{~kg}^{-1}$ with $50 \%$ of cowpea proportion in the silage [14]. The discrepancy in values could be due to corn being grown as a monoculture in the field, and having cowpea added to the silage only during the ensiling process, versus our study where cowpea and corn were grown simultaneously intercropped in the field. Overall, in years of average and above-average precipitation, intercropping of corn with crabgrass can maintain silage production (Figure 3), but with lower energy levels. However, intercropping of corn with cowpea will maintain high productivity and energy levels, and enhance silage crude protein (data not shown).

2016

Silage In Vitro True Dry Matter Digestibility $\left(\mathrm{g} \mathrm{kg}^{-1}\right)$

\section{7}

Silage In Vitro True Dry Matter

Digestibility $\left(\mathrm{g} \mathrm{kg}^{-1}\right)$
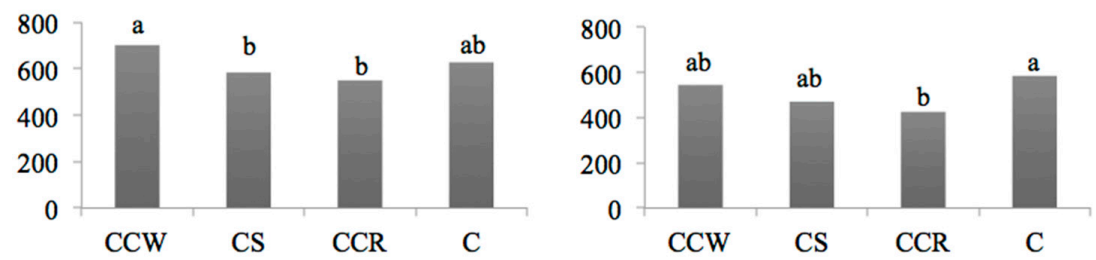

Figure 4. In vitro true dry matter digestibility differences $(p<0.05)$ of silage for corn grown as a monoculture (C), or grown interseeded with cowpea (CCW), sunn hemp (CS) or crabgrass (CCR). 


\section{Conclusions}

The intercropping systems studied did not reduce total silage productivity. Corn intercropped with sunn hemp had lowest corn agronomic characteristics following a drought event; therefore, we considered it a risky choice in regions where drought stress is possible. However, if precipitation is average or above average, only differences in plant population are found towards the end of the growing season, with corn grown as a monoculture having the lowest values. Forage production was highest most of the time when intercropping was conducted with sunn hemp, but forage nutritive value was higher in a mixture of corn intercropped with cowpea. Intercropping of cowpea with corn can enhance $\mathrm{CP}$ levels, while maintaining forage mass and energy levels. The choice of forage species to be intercropped with corn for silage production is important and from our results we conclude that cowpea might be the best option due to its ability to maintain yield and energy levels, while increasing $\mathrm{CP}$ levels. This increase in $\mathrm{CP}$ levels are due to cowpea's ability to increase $\mathrm{N}$-fixation of the system, therefore increasing sustainability by reducing fertilization costs. Even crabgrass showed a reduction in energy levels; thus, intercropping of this grass with corn may still be useful when used in integrated crop-livestock systems, in which they can be left behind with corn residue after harvesting to be grazed. Future studies evaluating the economical potential of these systems and determining weed suppression that may occur when intercropping these forages are necessary.

Author Contributions: R.L.G.N. conceived and designed the experiment; R.L.G.N. and M.D.C. performed the experiment and the measurements; R.L.G.N. analyzed the data, and was the main supervisor of the project. R.L.G.N. wrote the first draft, and M.D.C. contributed to discussion and writing of the paper.

Funding: This research received no external funding.

Acknowledgments: The authors would like to acknowledge the University of Tennessee Middle Tennessee AgResearch and Education Center for helping conduct our study and providing research facilities.

Conflicts of Interest: The authors declare no conflict of interest.

\section{References}

1. Hauggard-Nielsen, H.; Ambus, P.; Jensen, E.S. Interspecific competition, $\mathrm{N}$ use and interference with weeds in pea-barley intercropping. Field Crops Res. 2001, 70, 101-109. [CrossRef]

2. Hardin, B. Intercropping for more forage and less erosion. Agric. Res. 1996, 44, 15-16.

3. Contreras-Govea, F.E.; Lauriault, L.M.; Marsalis, M.; Angadi, S.; Puppala, N. Performance of forage sorghum-legume mixtures in southern High Plains, USA. Forage Grazinglands 2009, 7. [CrossRef]

4. Allen, V.G.; Brown, C.P.; Kellison, R.; Segarra, E.; Wheeler, T.; Dotray, P.A.; Conkwright, J.C.; Green, C.J.; Acosta-Martinez, V. Integrating cotton and beef production to reduce water withdrawal from the Orgallala Aquifer in the Southern High Plains. Agron. J. 2005, 97, 556-567. [CrossRef]

5. Kaspar, T.C.; Radke, J.K.; Laflen, J.M. Small grain cover crops and wheel traffic effects on infiltration, runoff and erosion. J. Soil Water Conserv. 2001, 56, 160-164.

6. Ruffo, M.L.; Bullock, D.G.; Bollero, G.A. Soybean yield as affected by biomass and nitrogen uptake of cereal rye in winter cover crop rotations. Agron. J. 2004, 96, 800-805. [CrossRef]

7. Sa, J.C.; Sulc, R.M.; Moraes, A. Carbon and nitrogen particle size fractions affected by winter grazing in Southern Brazil. In Proceedings of the ASA, CSSA, SSSA Annual Meetings, Madison, WI, USA, 21 July 2003.

8. Fisk, J.W.; Hesterman, O.B.; Shrestha, A.; Kells, J.J.; Harwood, R.R.; Squire, J.M.; Sheaffer, C.C. Weed suppression by annual legume cover crops in no-tillage corn. Agron. J. 2001, 93, 319-325. [CrossRef]

9. Entz, M.H.; Baron, V.S.; Carr, P.M.; Meyer, D.W.; Smith, S.R., Jr.; McCaughey, W.P. Potential of forages to diversify cropping systems in the Northern Great Plains. Agron. J. 2002, 94, 240-250. [CrossRef]

10. Fae, G.S.; Sulc, R.M.; Barker, D.J.; Dick, R.P.; Eastridge, M.L.; Lorenz, N. Integrating winter annual forages into a no-till corn silage system. Agron. J. 2009, 101, 1286-1296. [CrossRef]

11. Freitas, F.C.L.; Santos, M.V.; Machado, A.F.L.; Ferreira, L.R.; Freitas, M.A.M.; Silva, M.G.O. Behavior of corn cultivars intercropped with Brachiaria brizantha in the presence and absence of sprayed foramsulfuron + iodosulfuron-methyl. Planta Daninha 2008, 26, 215-221. [CrossRef] 
12. Silva, A.C.; Ferreira, L.R.; Silva, A.A.; Paiva, T.W.B.; Sediyama, C.S. Effects of reduced rates of fluazifop-P-butyl on soybean intercropped with Brachiaria brizantha. Planta Daninha 2004, 22, 429-435. [CrossRef]

13. Barducci, R.S.; Costa, C.; Crusciol, C.A.C.; Borghi, E.; Putanov, T.C.; Sarti, L.M.N. Production of Brachiaria brizantha and Panicum maximum with corn and nitrogen fertilization. Arch. Zootecnia 2009, 58, 211-222.

14. Contreras-Govea, F.E.; VanLeeuwen, D.M.; Angadi, S.V.; Marsalis, M.A. Enhances in crude protein and effects on fermentation profile of corn and forage sorghum silage with addition of cowpea. Forage Grazinglands 2013, 11. [CrossRef]

15. Hanlon, E.A.; Savoy, H.J. Procedures Used by State Soil Testing Laboratories in Southern Region of the United States; Southern Cooperative Series Bulletin; Clemson Experiment Station: Clemson, SC, USA, 2007; Volume D, p. 190.

16. Murray, I.; Cowe, I. Sample preparation. In Near Infrared Spectroscopy in Agriculture; Roberts, C.A., Workman, J., Jr., Reeves, J.B., III, Eds.; ASA: Madison, WI, USA, 2004; pp. 75-115.

17. Borghi, E.; Crusciol, C.A.C. Corn yield, spacing and intercropping modalities with Brachiaria brizantha in no-tillage system. Pesquisa Agropecuária Brasileira 2007, 42, 163-171. [CrossRef]

18. Neely, C.B.; Rouquette, F.M., Jr.; Morgan, C.L.; Smith, G.R.; Hons, F.M.; Rooney, W.L. Integrating legumes as cover crops and intercrops into grain sorghum production systems. Agron. J. 2018, 110, 1363-1378. [CrossRef]

19. Balkcom, K.S.; Reeves, D.W. Sunn-hemp utilized as a legume cover crop for corn production. Agron. J. 2004, 97, 26-31. [CrossRef]

20. Gelley, C.; Nave, R.L.G.; Bates, G. Forage nutritive value and herbage mass relationship of four warm-season grasses. Agron. J. 2016, 108, 1603-1613. [CrossRef]

21. Teutsch, C.D.; Fike, J.H.; Wilson, W.M. Yield, digestibility, and nutritive value of crabgrass as impacted by nitrogen fertilization rate and source. Agron. J. 2005, 97, 1640-1646. [CrossRef]

22. Schomberg, H.H.; Martini, N.L.; Diaz-Perez, J.C.; Phatak, S.C.; Balkcom, K.S.; Bhardwaj, H.L. Potential for using sunn hemp as a source of biomass and nitrogen for the Piedmont and Coastal Plain regions of the Southeastern USA. Agron. J. 2006, 99, 1448-1457. [CrossRef]

23. Crusciol, C.A.C.; Nascente, A.S.; Mateus, G.P.; Borghi, E.; Leles, E.P.; Santos, N.C.B. Effect of intercropping on yields of corn with different relative maturities and palisadegrass. Agron. J. 2013, 105, 599-606. [CrossRef]

24. Sawyer, J.E.; Pedersen, P.; Barker, D.W.; Diaz, D.A.R.; Albrecht, L. Intercropping corn and kura clover: Response to nitrogen fertilization. Agron. J. 2010, 102, 568-574. [CrossRef]

25. Pariz, C.M.; Costa, C.; Crusciol, C.A.C.; Meirelles, P.R.L.; Castilhos, A.M.; Andreotti, M.; Costa, N.R.; Martello, J.M.; Souza, D.M.; Sarto, J.R.W. Production and soil responses to intercropping of forage grasses with corn and soybean silage. Agron. J. 2016, 108, 2541-2553. [CrossRef]

26. Armstrong, K.L.; Albrecht, K.A. Effect of plant density on forage yield and quality of intercropped corn and lablab bean. Crop Sci. 2007, 48, 814-822. [CrossRef]

27. Contreras-Govea, F.E.; Marsalis, M.A.; Angadi, S.V.; Smith, G.; Laurialt, M.; VanLeeuwen, D.M. Fermentability aqnd nutritive value of corn and forage sorghum silage when mixed with lablab bean. Crop Sci. 2010, 51, 1307-1313. [CrossRef]

(C) 2018 by the authors. Licensee MDPI, Basel, Switzerland. This article is an open access article distributed under the terms and conditions of the Creative Commons Attribution (CC BY) license (http:// creativecommons.org/licenses/by/4.0/). 